\title{
The Evaluation of Athletic Extracurricular Management of Dr. Soetomo and Jalan Jawa Junior High School in Surabaya
}

\author{
Sulaiman $^{1}$, Amrozi Khamidi², Edy Mintarto ${ }^{2}$ \\ ${ }^{1}$ Master Student in Physical Education, Surabaya State University, Indonesia \\ ${ }^{2}$ Lecturer in Physical Education, Surabaya State University, Indonesia \\ Sulaiman.17070805016@mhs.unesa.ac.id
}

\begin{abstract}
One of the fundamental strategies in attempts to develop athletic sports in Surabaya was to conduct special training through athletic extracurricular activities in schools, hence it was the starting point for the discovery of potential athletes. The purpose of this study was to determine the strengths, weaknesses, opportunities, and Threat from athletic extracurricular management which included Planning, Organizing, Implementing and Supervising which was conducted by Dr. Soetomo and Jalan Jawa Junior High School in Surabaya. The approach used in this study was a qualitative approach and the type of evaluative research (Evaluation Research) used descriptive methods. The evaluation design used in this study was the SWOT Analysis. The results and conclusions of this study indicated that the athletic extracurricular management at Dr Soetomo Junior High School; The Planning was already a good program, The Organizing used the organizational structure and cooperation which already existed so the working mechanism was clear of its functions and parts, The Actuating contained the schedule of activities, the attendance of students and the coaches are well-monitored by the extracurricular coordinator, The Controlling implemented a routine evaluation that carried out at the end of the school year, but for the achievements have not been as the expectation. On the other hand, Jalan Jawa Junior High School implemented the management as; The Planning of this school did not have a good program, The Organizing included the involved cooperation of leaders, teachers and parents of students was very good, The Actuating related to the exercise did not run well, The Oversight represented almost every championship in Surabaya, Jalan Jawa Junior High School got good marks. The researchers have conducted more in-depth analysis of the strengths, weaknesses, opportunities, and Threat of athletic extracurricular management which included Planning, Organizing, Implementing and Supervising which was conducted by Dr Soetomo and Jalan Jawa Junior High School in Surabaya, furthermore resulting some recommendations for Dr. Soetomo and Jalan Jawa Junior High School.
\end{abstract}

Keywords

athletics, extracurricular management of D. Soetomo and Jalan Jawa junior high school in Surabaya; swot analysis

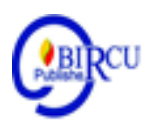

\section{Introduction}

School as an educational institution (institution) is a place where the educational process is carried out, has a complex and dynamic system in relation, the school is a place that is not just a gathering place for teachers and students, but is in a complex and interrelated arrangement. Therefore, schools are seen as an organization that requires more management. Another activity of school organizations is managing human resources (HR) which can be 
expected to produce quality graduates in accordance with the demands of community needs and in turn school graduates are expected to be able to contribute to national development.

Physical activity is an inseparable part of the life of living things, ranging from simple to very complex activities. As a living creature, humans need physical activity as an effort to maintain the existence of their lives. Every individual in his life must be doing physical activities both intentionally and unintentionally, because physical activities are carried out with diverse and diverse purposes.

One form of education implementation model that can be applied to the form of a model of developing educational organization that allows potential learners to achieve maximum performance is by optimizing extracurricular activities in schools. With the extracurricular activities of students who have special talents in the field of sports can develop optimally.

The extracurricular program is a continuation of the intracuricular program, where the basic movements and basic skills of certain sports are taught, thus the development of extracurricular activities must be based on the interests, talents and potential of students, but in organizing its operations it is a separate program, so it is necessary to pay attention to the problem of funding, teachers / trainer, facilities and infrastructure.

Extracurricular activities are very important because they are a place to channel talents and form achievements. With the existence of extracurricular students can increase knowledge, insight and develop their talents. Not all students have the potential and talent in sports and not all students know the potential and talent they have. So this requires a party who can direct the students so that the potential and talent can be distributed on target.

Achievement sports development programs are not only the responsibility of sports development institutions such as the Indonesian National Sports Committee (KONI), Sports Branch Management (PENGCAB) and Sports Clubs, but also the responsibility of the government, the community including educational institutions, namely schools. One of the fundamental strategies in efforts to develop athletic sports in the city of Surabaya is to conduct special coaching through athletic extracurricular activities in schools, because school is the starting point for finding potential athletes. Dr Soetomo Middle School and Jalan Jawa Surabaya Middle School are schools in which there are a series of athletic extracurricular activities.

Athletic extracurricular training is a superior extracurricular program in Dr Soetomo Middle School and Jalan Jawa Middle School in optimally increasing non-academic achievements, because it is realized that to improve academic achievement in line with regional and regular state junior high schools in Surabaya City is very heavy. This is because the academic input is very different compared to the Public Middle School in Surabaya City. As a strategic step to get a response and get an assessment from the community so that Dr Soetomo Middle School and Jalan Jawa Middle School remain Exist and of course can be known as well as other favorite public and private SMPs by optimizing Non-academic activities, one of which is athletic extracurricular activities.

Of course, to get a proud achievement is not easy, it requires early, special, tiered and sustainable coaching and good management of management from the organization or school therein. In the process of sports coaching the existence of Athletic Extracurricular in Schools is certainly very much needed as a place to foster outstanding athletic athletes for future, so athletes are expected to emerge not only in athletic clubs but also in extracurricular activities in schools in Surabaya. 


\section{Review of Literature}

According to Novan Ardy Wiyani (2013: 108) extracurricular activities are defined as educational activities carried out outside face-to-face lessons. These activities are carried out inside and outside the school environment to expand knowledge, enhance skills and internalize values, religious rules and social norms. Athletic Extracurricular is an extracurricular sports activity whose movements include, running, walking, throwing and jumping, which have become the oldest sports activities in human civilization.

Terry, (2000) management is a process or framework that involves the guidance or direction of a group of people towards organizational goals or real intentions. Of the several opinions all focus on coordinating the activities of existing resources in an organization to achieve goals. Terry, (2001) suggested that management has 4 functions, namely: (1) planning, (2) organizing, (3) moving, and (4) supervising or controlling), based on the theory, the researcher begins this research by looking from management functions are carried out properly.

\section{Research Method}

This type of research is a qualitative study, using SWOT Analysis. This study aims to get an idea of how strengths, weaknesses, opportunities and threats of athletic extracurricular management which include Planning, organizing, implementing, monitoring, supervision of Dr. Soetomo and Jalan Jawa Junior High School in Surabaya City.

Place of research. This research was carried out by Dr. Soetomo Junior High School (Jalan Manyar Rejo 1 / no 39) and Jalan Jawa Hunior High School (Jalan Ngagel Rejo Utara No 36-40) in Surabaya City. The research source is the informant or informant as the source of the data needed to find out the implementation of the management of the extracurricular activities of Dr. Soetomo Junior High School and Jalan Jawa Junior High School in the City of Surabaya. The sources of this research include: (1) Research Informants including: school principals, vice principals, Sports and health Physical Education teachers, athletic extracurricular coaches, parents of students and students who participate in athletic extracurricular activities.

In this study data collection techniques were carried out on primary data sources through observation and interviews, and on secondary data sources through documentation. Data analysis techniques will be carried out with qualitative descriptive analysis, of primary data obtained and secondary data obtained from sharing written documentation. Then make conclusions and recommendations.

\section{Result and Discussion}

\subsection{Athletics Extracurricular Management of Dr. Soetomo Junior High School}

a. Planning

1) Strength

Already have a predetermined program planning at the beginning of the new school year. Have a written training program or work program made at the beginning of the new school year. Recruitment of students who participate in athletic extracurricular activities through a mechanism, beginning with the introduction of extracurricular activities, exploring interests and observing PJOK teachers and extracurricular coaches. Recruitment 
of trainers or coaches through coordination and background, experience and licensing considerations. Athletic extracurricular needs have been budgeted in the RAB or Budget Plan that was determined one year in advance. There is a achievement target in one semester.

2) Weaknesses

Not all of the facilities for athletic extracurricular activities owned by the school were fulfilled. There is less interest in students participating in athletic extracurricular activities than other extracurricular activities.

3). Opportunity

In every event and championship held by the Department of Education, Department of Youth and Sports and other agencies, the School always supports and supports. Trainers and assistant trainers already have a national basic level physical condition trainer license or certificate.

4). Threat

Private schools depend on BOSNAS (National Student Operational Assistance) or BOPDA (Regional Operational Assistance). If the number of new student admissions falls, the amount of assistance from BOSNAS (National Student Operational Assistance) or BOPDA (Regional Operational Assistance) also falls, then the need for activities athletic extracurricular activities will also decrease.

\section{b. Organizing}

1) Strength

School Has Athletic Extracurricular Organizational Structure. The function and performance of the deputy headmaster for Student Affairs, sports and health physical education teachers and extracurricular coaches in accordance with the distributed job descriptions. Teacher cooperation that is involved and not involved in athletic extracurricular activities is very good.

2) Weaknesses

There is no collaboration with athletic clubs in Surabaya, to further maximize the coaching of athletic extracurricular in schools. There is no collaboration with the existing Athletic Parent Organization in Surabaya.

3). Opportunity

Athletic extracurricular activities are supported and supported by the IKA or Dr Soetomo Junior High School alumni association. Collaborate with the global mass media of the archipelago to publicize school activities including athletic extracurricular activities. Have an internal newspaper to publicize the activities carried out at school, including athletic extracurricular activities

4). Threat

There are no sponsors who support athletic extracurricular activities.

\section{c. Actuating}

1). Strength

Extracurricular schedule distribution has been well arranged by the Extracurricular Coordinator. Extracurricular activities Well monitored by extracurricular coordinators who monitor the attendance of coaches and students who take part in athletic extracurricular activities every day. Leaders always provide motivation and evaluation in every extracurricular activity. 
2). Weaknesses

Implementation of Coaching is only limited to 3 years at school so achievement cannot be optimal.

\section{3). Opportunity}

The frequency of the exercise is carried out 3 times a week, which is held on Tuesdays, Thursdays and Afternoon weeks inside and outside the school (KONI Field). Students who have graduated from Dr Soetomo Middle School still want to take part in the training at Dr Soetomo Middle School. Many students from elementary, junior high, vocational, and high schools around Dr Soetomo Middle School took part in joint exercises. There are assistant assistants and alumni who help with athletic extracurricular activities.

4). Threat

Lack of support from some parents for athletic extracurricular activities. The coach or trainer picks up students during training outside (Thor Square) because the training ground is far from home.

\section{d. Controlling}

1). Strength

Routine evaluation is carried out at the end of each school year, to determine the development of athletic and other extracurricular extracurricular achievements. With extracurricular activities can shape the personality of students who are disciplined, responsibility both inside and outside of school.

2) Weaknesses

Conformity between planning and implementation has not been maximized. Achievement sometimes is not as expected by the school.

3). Opportunity

Students who are the result of fostering athletic extracurricular activities are accepted at high schools or state vocational schools through the Achievement Path. With the achievements obtained by students, the community respected the existence of Dr. Soetomo Middle School, so that it affected the acceptance of new students the following year.

4). Threat

There is no appreciation program or scholarship from schools for students and coaches who excel, so that it slightly influences motivation and enthusiasm.

\subsection{Extracurricular Management of Athletics at Jalan Jawa Junior High School}

\section{a. Planning}

1) Strength

There are targets and expectations of achievement from the school in one school year, because athletics is the leading extracurricular at Jalan Jawa Junior High School.

2) Weaknesses

The school does not yet have an athletic extracurricular activity program planning. The school has not yet written a training program for athletic extracurricular activities. The coach or trainer does not have a training license or certificate. Interests of students who take part in athletic extracurricular activities are few compared to other extracurricular activities. Infrastructure facilities (long jump field, bullets, javelins and physical training support equipment) owned by the school for athletic extracurricular activities are very lacking or nonexistent, so at the time of borrowing practice. 
3). Opportunity

Athletic extracurricular recruitment involves parents of students at the beginning of the school year meeting, to socialize extracurricular activities at school and what achievements have been obtained, so parents can direct students to determine their talents and interests.

4). Threat

Private schools depend on BOSNAS (National Student Operational Assistance) or BOPDA (Regional Operational Assistance). If the number of new student admissions falls, the amount of assistance from BOSNAS (National Student Operational Assistance) or BOPDA (Regional Operational Assistance) also falls, then the need for activities athletic extracurricular activities will also decrease.

\section{b. Organizing}

1) Strength

The cooperation between leaders and teachers at Jalan Jawa Junior High School, both those involved and not involved in athletic extracurricular activities, is very good, because it is in the interest of the school.

2) Weaknesses

There is no extracurricular organizational structure. There is no collaboration with athletic clubs in Surabaya. There is no collaboration with the parent Athletics Organization in Surabaya.

3). Opportunity

4). Threat

Parents always provide support and assistance during practice and competitions.

There is no collaboration with sponsors or other parties that support athletic extracurricular activities because the school is small.

\section{c. Actuating}

1) Strength

Scheduling of athletic extracurricular activities is well organized so it does not interfere with the learning process.

2) Weaknesses

When the coach is unable to attend training activities are closed, so the training program cannot run properly.

3). Opportunity

Extracurricular activities are carried out 2-3 times a week which are carried out in schools and outside schools (KONI Field Surabaya).

4). Threat

The available school field is very limited and in the middle of the village, which is also used by residents for sports activities in the afternoon, so that the exercise cannot run optimally.

\section{d. Controlling}

1) Strength

School evaluations are conducted at the end of each year, to see the development of athletic extracurricular activities. There is an appreciation program or scholarship for high- 
achieving students and coaches to motivate them to further improve the achievements and performance of coaches.

2) Weaknesses

There is no match between the planning and implementation of athletic extracurricular activities.

3). Opportunity

Students who participate in athletic extracurricular activities have better discipline than other students. Students who receive the results of athletic extracurricular training are accepted at state high schools or vocational high schools through achievement pathways. Students from athletic extracurricular training continue to the Faculty of Sports Science, Surabaya State University.

4). Threat

If the National Student Operational Assistance (BOSNAS) and Regional Student Operational Assistance (BOPDA) have not come down or are late, then funding is stalled, including incentive trainers who are threatened to be delayed. Achievement achievements sometimes cannot be fulfilled because they have to compete with students from other schools who are members of the Club or training camp.

\section{Conclusion}

The results of the study can be concluded that management consists of planning, organizing, implementing and monitoring analyzed based on strengths, weaknesses, opportunities and threats that exist in Dr. Soetomo Junior High School:

1. Planning.

There is already a planning program that includes student programs, budget planning, training programs, student recruitment and mentoring in accordance with competencies. Despite this lack of interest in students who take part in athletic extracurricular activities and activity budgets is an obstacle, because schools still depend on BOSNAS and BOPDA assistance from the government.

2. Organizing

The organizational structure already exists so that the work mechanism of the leaders and teachers involved in this activity is clear in its functions and parts. There is already cooperation with alumni and the mass media, but the school has not collaborated with any parent organizations and athletic clubs in the city of Surabaya.

3. Actuating

The schedule of activities, attendance of students and coaches are well monitored by the extracurricular coordinator.

4. Controlling

Routine evaluations are carried out at the end of the school year, but achievements have not been as expected.

Whereas the athletic extracurricular management at Jalan Jawa Junior High School shows that

1. Planning.

Schools have achievement targets in one school year, but there are many weaknesses that need to be pursued, among schools not yet maximizing planning 
programs, student programs, written training programs, and coaches who have certificates according to their competencies.

2. Organizing

The collaboration between leaders, teachers and parents of students involved is very good, because the athletic extracurricular activities at Jalan Jawa Junior High School are excellent extracurricular, but there has been no attempt to work together with the parent organization, clubs and sponsors to support the activity.

3. Actuating

The schedule of activities has been arranged well by the students, but the implementation of the training did not go well, because the field used was also used by residents to do sports activities in the afternoon, because the school was located in the middle of the village. So that the exercise was more often done in the KONI field far from home.

4. Controlling

In almost every Road Java Middle School championship achievers, many students resulting from athletic extracurricular training at this school are accepted in high school or vocational school through achievement channels provided by the government.

\section{References}

Arikunto, Suharsimi (2007). Research Management. Jakarta: Rineka Cipta.

Creswell, J.W. (2010). Research Design: Qualitative, Quantitative, and Mixed Approaches. Yogjakarta: PT. Student Library

George Terry. (2010). Fundamentals of management. Eleventh Printing. Jakarta PT Bumi Aksara.

Harsuki (2012). Introduction to Sports Management. Jakarta: PT Raja Grafindo

Maksum, Ali. (2011). Psikologi Olahraga: Teori dan Aplikasi. Surabaya: Unesa University Press

Moleong, Lexy. J. (2007). Qualitative Research Methodology. Bandung: Remaja Rosdakarya

Nanang Fatttah. (2004). Platform for Educational Management. Bandung: Remaja Rosdakarya.

Sugiono. 2015. Quantitative, Qualitative, and R\&D Research Methods. Publisher: Alfabeta. Bandung

Feldman, Amy F and Jennifer L. Matjasko (2005). Journal: The Role of School-Based Extracurricular Activities in Adolescent Development: A Comprehensive Review and Future Directions.Review of Educational Research Summer.Vol.75,No2, 159210. Austin: University of Texas.

Balyi, Istvan. 2001. Journal: Sport System Building and Long-term Athlete Developmeni in British Columbia.Canada: SportMed BC.

Boccaro, Kanters, Casper and Forrester.2008. Sport Physical Education, Extracurricular Sports, and Lifelong Active Living. Journal of teaching in physical education,27,155-166.Canada: Human Kinetics.

Gan, Noddir and Lywordraeth Cynulliad Cymru, 2009: 45-70) .The proportion of young people participating in extracurricular activity decreases with age. 
Duda, 1989; Holland and Andre, 1994; Jaffee and Ricker, 1993 in Binsinger., et al, 2006:123-129. .In particular, participation in extracurricular sports has been linked to higher self-esteem.

Aqib, Zainal dan Sujak. 2011. Panduan dan Aplikasi Pendidikan Karakter. Jakarta: Gaung Persada Press.

Echols, John M. and Hassan Shadily. 2000. Kamus Inggris-Indonesia. Jakarta: Gramedia Pustaka Utama

Yunanda, M. 2009. Educational Evaluation. Jakarta: Balai Pustaka.

Ismail Solihin. (2012). Strategic Management. Jakarta: Erlangga.

Nugroho, Riant. (2009). Public Policy. Jakarta:PT Elex Media komputindo.

Pontas M.ardede (2005). Operations and Production Management. Yogyakarya: Andi Offset. 